DOI: https://doi.org/10.24127/ajpm.v9i1.2659

\title{
PENGARUH MODEL PEMBELAJARAN BERBASIS PENEMUAN DAN LINGKUNGAN TERHADAP KEMAMPUAN PEMECAHAN MASALAH MATEMATIKA MELALUI META ANALISIS
}

\author{
Aryo Andri Nugroho ${ }^{1}$, Ida Dwijayanti ${ }^{2}$, Prasetyo Yuda Atmoko ${ }^{3}$ \\ 1,2,3 Pendidikan Matematika, Universitas PGRI Semarang, Indonesia \\ E-mail: $\quad$ aryoandrinugroho@gmail.com ${ }^{1)}$ \\ idadwijayanti@upgris.ac.id $^{2)}$ \\ prasetyoyuda66@gmail.com ${ }^{3)}$
}

Received 25 January 2020; Received in revised form 24 February 2020; Accepted 28 March 2020

\begin{abstract}
Abstrak
Tujuan penelitian ini adalah untuk mengetahui pengaruh model pembelajaran berbasis penemuan dan model pembelajaran berbasis lingkungan terhadap kemampuan pemecahan masalah matematika selama 4 tahun terakhir (2016-2019) di area Jawa Tengah. Metode dalam penelitian ini menggunakan meta analisis dan instrumen penelitian berupa pedoman observasi (langkah-langkah model pembelajaran berbasis penemuan dan lingkungan, indikator pemecahan masalah) dan rincian sumber data. Prosedur yang dilakukan pada penelitian ini yaitu : 1) Menetapkan domain penelitian yang akan dirangkum. 2) Memilih jenis publikasi yang dikumpulkan. 3) Mengumpulkan hasil penelitian atau literature. 4) Mencatat datadata penelitian. 5) Menghitung effect size setiap sumber atau penelitian. Berdasarkan hasil penelitian menunjukkan pada model pembelajaran berbasis penemuan yaitu nilai effect size pada tahun 2016 sebesar 0,941, tahun 2017 sebesar 0,777, tahun 2018 sebesar 0,712 dan tahun 2019 sebesar 0,618. Sedangkan pada model pembelajaran berbasis lingkungan yaitu nilai effect size pada tahun 2016 sebesar 1,177 , tahun 2017 sebesar 1,866, tahun 2018 sebesar 1,070 dan tahun 2019 sebesar 0,866. Selama tahun 2016-2019 rata-rata kemampuan pemecahan masalah matematis menggunakan model pembelajaran berbasis lingkungan lebih baik daripada menggunakan model pembelajaran berbasis penemuan yang ditunjukkan dengan rata-rata effect size model pembelajaran berbasis penemuan sebesar 0,762 dan model pembelajaran berbasis lingkungan sebesar 1,245.
\end{abstract}

Kata kunci: Effect size; kemampuan pemecahan masalah; lingkungan; meta analisis; penemuan.

\begin{abstract}
Problem solving ability is an important ability to master because it aims to create students' thinking processes that are able to apply in everyday life. The purpose of this study was to determine the effect of discovery-based learning models and environment-based learning models on the ability to solve mathematical problems for the past 4 years (2016-2019) in the Central Java area. The method in this study using meta-analysis and research instruments in the form of observation guidelines (steps of the discovery-based learning model and the environment, indicators of problem-solving) and details of the source of data. The procedures performed in this study are: 1) Establishing the research domain to be summarized. 2) Choose the type of publication that is collected. 3) Gathering the results of research or literature. 4) Record research data. 5) Calculate the effect size per source or research. From the results of the study show the discovery-based learning model that is the value of the effect size in 2016 amounted to 0.941, in 2017 amounted to 0.777, in 2018 amounted to 0.712 and in 2019 amounted to 0.618. Whereas the environment-based learning models the effect size value in 2016 amounted to 1.177, in 2017 amouted to 1.866, in 2018 amounted to 1.070 and in 2019 amounted to 0.866. During 2016-2019 the average mathematical problem solving ability using an environment based learning model is better than using a discovery based learning model as indicated by the average effect size of the discovery based learning model by 0.762 and the environment based learning model by 1.245.
\end{abstract}

Keywords: Discovery; effect size; environmental; meta analysis; problem solving. 
DOI: https://doi.org/10.24127/ajpm.v9i1.2659

\section{PENDAHULUAN}

Matematika merupakan salah satu pelajaran yang bersinggungan dengan pemecahan masalah dalam kehidupan sehari-hari, tetapi dalam pembelajaran matematika seringkali dianggap sebagai sesuatu yang sulit dan kurang menarik. Berdasarkan Permendiknas No 22 tahun 2006 salah satu kemampuan yang harus dimiliki oleh siswa dalam mempelajari matematika adalah kemampuan pemecahan masalah. Sembiring (2019) menyatakan melalui meta analisis pada pemecahan masalah terjadi peningkatkan kemampuan pemecahan masalah matematika yang ditandai dari peningkatan hasil belajar siswa dengan pemilihan model pembelajaran yang tepat.

Salah satu tujuan belajar matematika adalah agar siswa dapat memiliki keterampilan dalam menyelesaikan suatu masalah (Islamiah, 2018). Selain itu, tujuan dari pemecahan masalah yaitu untuk menciptakan proses berpikir siswa yang mampu mengaplikasikan di dalam kehidupan sehari-hari (Al Ayyubi, dkk., 2018; Bernard, dkk., 2018). Pemecahan masalah didefinisikan sebagai suatu usaha untuk mencari solusi dari suatu permasalahan yang muncul dalam kehidupan sehari-hari (Polya, 1973). Pada penelitian ini pemecahan masalah didefinisikan suatu aktivitas untuk mencari penyelesaian dari masalah matematika yang dihadapi dengan menggunakan semua bekal pengetahuan matematika yang dimiliki. Aspek kemampuan pemecahan masalah matematika berdasarkan polya yaitu memahami masalah yang meliputi kemampuan mengidentifikasi unsurunsur yang diketahui dan ditanyakan, membuat rencana pemecahan masalah, melaksanakan rencana pemecahan masalah dan menafsirkan solusi yang diperoleh (Nugroho, 2019). Suatu permasalahan dalam pemecahan masalah juga dapat didekati dengan budaya daerah untuk mengenal kehidupan sehari-hari dari siswa sehingga siswa mudah untuk menyelesaikannya (Utami, 2018). Oleh karena itu, dibutuhkan keterampilan aplikatif dalam berpikir untuk menghadapi situasi yang muncul dalam kehidupan sehari-hari.

Pada pelaksanaan pembelajaran diperlukan suatu model pembelajaran yang inovatif untuk meningkatkan kemampuan siswa terutama dalam hal penyelesaian sebuah masalah. Adapun beberapa model pembelajaran yang dapat meningkatkan kemampuan pemecahan masalah diantaranya yaitu model pembelajaran berbasis penemuan dan model pembelajaran berbasis lingkungan. Model pembelajaran berbasis penemuan merupakan salah satu model pembelajaran yang berpusat pada siswa mengenai proses pembelajaran matematika untuk memperoleh gambaran yang obyektif (Widayati, 2018).

Model pembelajaran berbasis penemuan juga dapat membantu siswa untuk menciptakan disiplin ilmu dan keterampilan intelektual yang dibutuhkan untuk mengajukan pertanyaan dan menemukan jawaban berdasarkan rasa ingin tahunya (Rangkuti, 2018). Model pembelajaran berbasis penemuan menekankan kepada siswa untuk dapat menemukan sendiri permasalahan yang diberikan oleh guru dan model ini dianggap sesuai diterapkan dalam pendidikan di Indonesia (Suryany, 2018). Bentuk pembelajaran berbasis penemuan diantaranya yaitu model pembelajaran discovery learning dan model pembelajaran inquiri. Sedangkan model pembelajaran berbasis lingkungan 
DOI: https://doi.org/10.24127/ajpm.v9i1.2659

merupakan pembelajaran yang memanfaatkan realita dan lingkungan dalam proses pembelajaran.

Pembelajaran berbasis lingkungan adalah pembelajaran yang menekankan pada lingkungan sebagai media atau sumber belajar. Pembelajaran berbasis lingkungan merupakan implementasi dari pendidikan lingkungan yang dilakukan secara formal (Wuryastuti, 2013). Pembelajaran berbasis lingkungan juga mengaitkan isu lokal dan global, mengorganisir siswa untuk belajar, membantu penyelidikan mandiri dan kelompok (Nismawati, 2019). Bentuk pembelajaran berbasis lingkungan diantaranya yaitu model pembelajaran Contextual Teaching and Learning (CTL) dan Realistic Mathematic Education (RME).

Kebaruan pada penelitian ini yaitu penelitian dengan menggunakan metode meta analisis selama empat tahun terakhir (2016-2019) pada model pembelajaran berbasis penemuan dan model pembelajaran berbasis lingkungan terhadap kemampuan pemecahan masalah matematika. Meta analisis merupakan kajian atas sejumlah hasil penelitian dalam masalah yang sejenis untuk memperoleh suatu kesimpulan secara umum. Meta analisis dilakukan pada penelitian ini dengan cara merangkum data penelitian, mereview dan menganalisis data penelitian dari beberapa hasil penelitian yang sudah ada sebelumnya (Anugraheni, 2018). Meta analisis merupakan analisis sistematis dengan menggabungkan data dari banyak penelitian untuk menilai efektivitas temuan dan signifikansi statistik (wahyuningsih, 2019). Meta analisis juga dapat digunakan untuk perhitungan angka dan statistik dalam menyusun dan membuat ekstrasi dari suatu informasi yang bersifat kuantitatif (Anggreni, 2019).

Meta analisis pada penelitian ini digunakan untuk mengetahui pengaruh model pembelajaran berbasis penemuan dan model pembelajaran berbasis lingkungan terhadap kemampuan pemecahan masalah matematika. Hasil penelitian yang diperoleh pada tiap penelitian diubah menjadi besar pengaruh atau lebih dikenal dengan effect size (ES). Menurut (Purwati, 2017) effect size merupakan ukuran yang pasti. Effect size didefinisikan sebagai hasil pengurangan mean kelompok eksperimen dengan mean kelompok kontrol pada veriabel kriteria dibagi dengan simpangan baku dari kelompok kontrol.

Berdasarkan permasalahan maka tujuan penelitian ini untuk mengetahui 1) Pengaruh model pembelajaran berbasis penemuan terhadap kemampuan pemecahan masalah matematika, 2) Pengaruh model pembelajaran berbasis lingkungan terhadap kemampuan pemecahan masalah matematika, 3) Melihat mana yang lebih baik antara model pembelajaran berbasis lingkungan dan model pembelajaran berbasis penemuan terhadap kemampuan pemecahan masalah matematika, 4) Faktor yang menyebabkan terjadi perbedaan pengaruh model pembelajaran berbasis lingkungan dan model pembelajaran berbasis penemuan terhadap kemampuan pemecahan masalah matematika.

\section{METODE PENELITIAN}

Jenis penelitian yang digunakan dalam penelitian ini yaitu penelitian survey yang bersifat deskripsif. Penelitian ini dilaksanakan di perguruan tinggi yang terletak di area Jawa Tengah. Teknik sampling yang 
digunakan dalam penelitian ini adalah teknik purposive sampling. Berdasarkan data hasil penelitian yang diperoleh tentang kemampuan pemecahan masalah matematika pada model pembelajaran berbasis penemuan sejumlah 8 hasil penelitian dengan sampel 264 siswa dan pada model pembelajaran berbasis lingkungan sejumlah 8 hasil penelitian dengan sampel 250 siswa. Hasil penelitian yang diambil meliputi area Jawa Tengah pada rentang waktu tahun 2016 - 2019 yang berkesinambungan setiap tahunnya.

Prosedur dalam penelitian ini disesuaikan dengan tahapan-tahapan meta analisis yang disarankan oleh Glass (1981) adalah sebagai berikut. 1) menetapkan domain penelitian yang akan dirangkum, 2) memilih jenis publikasi yang dikumpulkan, 3) mengumpulkan hasil penelitian atau literature, 4) mencatat data-data penelitian, 5) menghitung effect size setiap sumber atau penelitian. Instrumen yang digunakan pada penelitian ini yaitu pedoman observasi (langkahlangkah model pembelajaran berbasis penemuan dan lingkungan, indikator pemecahan masalah) dan rincian sumber data.

Teknik analisis data dalam penelitian ini bertujuan untuk mengetahui seberapa besar perbandingan pengaruh (effect size) dalam model pembelajaran berbasis penemuan dan model pembelajaran berbasis lingkungan terhadap kemampuan pemecahan masalah matematika dan faktor-faktor yang mempengaruhi model pembelajaran berbasis penemuan dan model pembelajaran berbasis lingkungan dalam jangka waktu 4 tahun terakhir (2016 - 2019).

Teknik analisis data dalam penelitian ini menggunakan metode meta analisis yaitu menghitung nilai effect size pada setiap penelitian per tahunnya. Adapun cara mencari effect size dalam penelitian yang digunakan adalah:

$$
E S=\frac{\overline{x_{E}}-\overline{x_{c}}}{S D_{c}}
$$

Keterangan:

$$
\begin{aligned}
E S= & \text { Effect size (biasanya diberi } \\
& \operatorname{simbol} \alpha \text { atau } \Delta) \\
\overline{x_{E}}= & \text { Mean (rerata) kelompok } \\
& \text { eksperimen. } \\
\overline{x_{c}=} & \begin{array}{l}
\text { Mean (rerata) kelompok } \\
\text { kontrol. }
\end{array} \\
S D_{c}= & \begin{array}{l}
\text { Simpangan baku kelompok } \\
\text { kontrol. }
\end{array}
\end{aligned}
$$

Kriteria effect size dengan mengadaptasi dari Cohen (Anggreni, 2019) sebagai berikut:

$\begin{array}{ll}0,00<E S \leq 0,20 & : \text { kurang } \\ 0,20<E S \leq 0,50 & : \text { rendah } \\ 0,50<E S \leq 1,00 & \text { : sedang } \\ E S>1,00 & \text { : tinggi }\end{array}$

\section{HASIL DAN PEMBAHASAN}

\section{Pengaruh model pembelajaran berbasis penemuan terhadap kemampuan pemecahan masalah matematika}

Pengaruh model pembelajaran berbasis penemuan terhadap kemampuan pemecahan masalah matematika selama 4 tahun terakhir dilakukan melalui perhitungan effect size dengan melihat rata-rata kelas eksperimen $\left(\bar{x}_{E}\right)$, rata-rata kelas kontrol $\left(\bar{x}_{K}\right)$ dan standar deviasi kelas kontrol $\left(s_{K}\right)$. Data-data tersebut berasal dari hasil penelitian yang tidak dipublikasikan dan terletak di perpustakaan yang berada di Jawa Tengah tepatnya di Universitas PGRI Semarang dan Universitas Islam Negeri Walisongo Semarang dari tahun 2016 sampai tahun 2019. Berikut adalah tabel 
DOI: https://doi.org/10.24127/ajpm.v9i1.2659

data-data perhitungan effect size berdasarkan hasil penelitian dari tahun 2016 sampai tahun 2019.

Tabel 1. Nilai effect size model pembelajaran berbasis penemuan.

\begin{tabular}{ccccccc}
\hline Tahun & $\boldsymbol{n}_{\boldsymbol{E}}$ & $\overline{\boldsymbol{x}}_{\boldsymbol{E}}$ & $\boldsymbol{n}_{\boldsymbol{K}}$ & $\overline{\boldsymbol{x}}_{\boldsymbol{K}}$ & $\boldsymbol{S}_{\boldsymbol{K}}$ & $\boldsymbol{E S} / \boldsymbol{\Delta}$ \\
\hline 2016 & 33 & 84,273 & 32 & 68,748 & 12,91 & 1,202 \\
& 32 & 80,375 & 32 & 74,218 & 9,047 & 0,680 \\
2017 & 38 & 85,789 & 38 & 82,552 & 6,233 & 0,519 \\
& 34 & 85,882 & 36 & 76,389 & 8,67 & 1,095 \\
2018 & 34 & 79,617 & 34 & 73,058 & 12,902 & 0,508 \\
& 30 & 80,000 & 30 & 71,1 & 7,761 & 1,147 \\
2019 & 30 & 79,733 & 30 & 74,8 & 7,747 & 0,637 \\
& 33 & 80,667 & 34 & 72,147 & 12,929 & 0,659 \\
\hline
\end{tabular}

Tabel 2. Nilai effeect size model pembelajaran berbasis penemuan setiap tahun.

\begin{tabular}{cccccc}
\hline Tahun & $\mathbf{n}$ & $\overline{\mathbf{x}}_{\mathbf{E}}$ & $\overline{\mathbf{x}}_{\mathbf{K}}$ & $\mathbf{S}_{\mathbf{K}}$ & $\mathbf{E S} / \Delta$ \\
\hline 2016 & 66 & 81,106 & 70,384 & 11,397 & 0,941 \\
2017 & 72 & 85,833 & 79,554 & 8,084 & 0,777 \\
2018 & 64 & 79,797 & 72,141 & 10,751 & 0,712 \\
2019 & 62 & 80,129 & 73,413 & 10,862 & 0,618 \\
\hline
\end{tabular}

Berdasarkan hasil perhitungan effect size pada Tabel 1 nilai effect size terbesar terdapat pada hasil penelitian pertama pada tahun 2016 yaitu sebesar 1,202, sedangkan nilai effect size terkecil pada hasil penelitian pertama pada tahun 2018 yaitu sebesar 0,508. Pada Tabel 2, effect size tahun 2016, 2017, 2018, dan 2019 tergolong dalam kriteria effect size sedang. Besarnya nilai effect size model pembelajaran berbasis penemuan terhadap kemampuan pemecahan masalah disajikan pada Gambar 1.

Nilai effect size dari tahun 2016 ke tahun 2019 mengalami penurunan (Gambar 1), artinya bahwa model pembelajaran berbasis penemuan terhadap kemampuan pemecahan masalah matematika mengalami penurunan dalam penggunaannya pada setiap tahunnya.

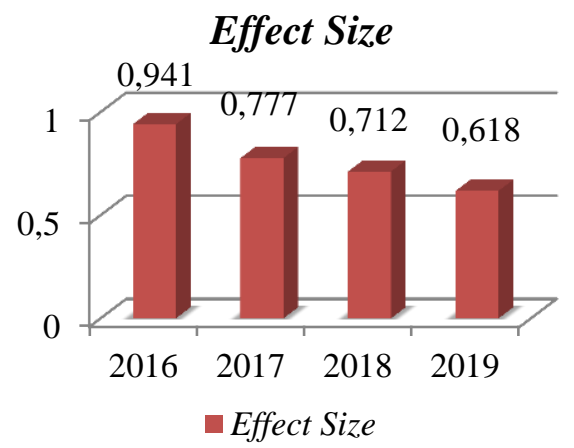

Gambar 1. Diagram nilai effect size model pembelajaran berbasis penemuan setiap tahun.

Hal ini perlu diperhatikan kembali terkait penggunaan pembelajaran berbasis penemuan, termasuk 
DOI: https://doi.org/10.24127/ajpm.v9i1.2659

bagaimana menganalisis kebutuhan siswanya serta materi yang akan diajarkan sehingga dalam pelaksanaannya saat menggunakan pembelajaran berbasis penemuan dapat memperoleh hasil yang maksimal. Ini sejalan dengan penelitian Gustika (2018) bahwa pembelajaran dengan menerapkan model pembelajaran penemuan dapat meningkatkan hasil belajar siswa. Selain itu, pembelajaran dengan menggunakan penemuan dapat berpengaruh positif pada prestasi siswa dalam proses pembelajaran matematika (Setiawan, 2018).

\section{Pengaruh model pembelajaran berbasis lingkungan terhadap kemampuan pemecahan masalah matematika}

Pengaruh model pembelajaran berbasis lingkungan terhadap kemampuan pemecahan masalah matematika selama 4 tahun terakhir dilakukan melalui perhitungan effect size pada hasil penelitian setiap judul dan setiap tahunnya. Data yang diperlukan untuk menghitung effect size yaitu, rata-rata kelas eksperimen $\left(\bar{x}_{E}\right)$, rata-rata kelas kontrol $\left(\bar{x}_{K}\right)$ dan standar deviasi kelas kontrol $\left(s_{K}\right)$. Data-data tersebut berasal dari penelitian yang tidak dipublikasikan dan terletak di perpustakaan yang berada di Jawa Tengah tepatnya di Universitas PGRI Semarang dan Universitas Islam Negeri Walisongo Semarang dari tahun 2016 sampai dengan tahun 2019. Data perhitungan effect size berdasarkan hasil penelitian tahun 2016 sampai dengan tahun 2019 dijasikan pada Tabel 3.

Berdasarkan hasil perhitungan effect size pada Tabel 3 nilai effect size terbesar pada hasil penelitian pertama pada tahun 2016 yaitu sebesar 1,841, sedangkan untuk nilai effect size yang terkecil pada hasil penelitian kedua pada tahun 2016 yaitu sebesar 0,299.

Tabel 3. Nilai effect size model pembelajaran berbasis lingkungan.

\begin{tabular}{ccccccc}
\hline Tahun & $\boldsymbol{n}_{\boldsymbol{E}}$ & $\overline{\boldsymbol{x}}_{\boldsymbol{E}}$ & $\boldsymbol{n}_{\boldsymbol{K}}$ & $\overline{\boldsymbol{x}}_{\boldsymbol{K}}$ & $\boldsymbol{S}_{\boldsymbol{K}}$ & $\boldsymbol{E S} / \Delta$ \\
\hline \multirow{2}{2}{2016} & 32 & 79,062 & 32 & 70,906 & 15,015 & 1,841 \\
& 30 & 81,067 & 30 & 47,633 & 10,008 & 0,299 \\
2017 & 32 & 85,875 & 32 & 74,125 & 6,379 & 0,542 \\
& 36 & 89.5 & 35 & 75,657 & 7,352 & 0,531 \\
2018 & 30 & 85,654 & 30 & 73,649 & 8,116 & 0,676 \\
& 28 & 74,178 & 28 & 66,643 & 9,036 & 1,199 \\
2019 & 34 & 74,147 & 34 & 67.735 & 9,179 & 1,431 \\
& 28 & 87,37 & 29 & 77,778 & 5,235 & 0,546 \\
\hline
\end{tabular}

Tabel 4. Nilai effect size model pembelajaran berbasis lingkungan setiap tahun

\begin{tabular}{cccccc}
\hline Tahun & $\boldsymbol{n}$ & $\overline{\boldsymbol{x}}_{\boldsymbol{E}}$ & $\overline{\boldsymbol{x}}_{\boldsymbol{K}}$ & $\boldsymbol{S}_{\boldsymbol{K}}$ & $\boldsymbol{E S} / \Delta$ \\
\hline 2016 & 62 & 80,032 & 59,645 & 17,311 & 1,177 \\
2017 & 68 & 87,794 & 74,925 & 6,896 & 1,866 \\
2018 & 58 & 80,114 & 70,267 & 9,200 & 1,070 \\
2019 & 62 & 79,919 & 72,127 & 8,995 & 0,866 \\
\hline
\end{tabular}


DOI: https://doi.org/10.24127/ajpm.v9i1.2659

Pada Tabel 4, effect size tahun 2016, 2017, 2018 tergolong dalam kriteria effect size tinggi dan effect size tahun 2019 tergolong dalam kriteria effect size sedang.Besarnya nilai effect size model pembelajaran berbasis lingkungan terhadap kemampuan pemecahan masalah matematis disajikan pada Gambar 2.

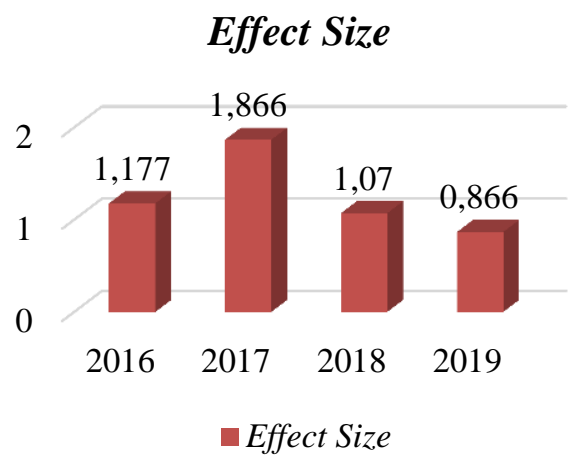

Gambar 2 Nilai effect size model pembelajaran berbasis lingkungan setiap tahun

Berdasarkan Gambar 2, dapat dilihat bahwa nilai effect size model pembelajaran berbasis lingkungan mengalami kenaikan dari tahun 2016 ke tahun 2017 dan mengalami penurunan dari tahun 2017 ke tahun 2019. Jadi dapat dikatakan bahwa nilai effect size model pembelajaran berbasis lingkungan terhadap kemampuan pemecahan masalah matematika jika dilihat dari tahun ke tahun cenderung tidak stabil setiap tahunnya. Hal ini perlu dikaji kembali terkait penggunaan pembelajaran berbasis lingkungan, termasuk langkah-langkah dalam penggunaan model pembelajaran berbasis lingkungan serta menganalisis dan mengevaluasi pembelajaran berbasis lingkungan yang sudah terlaksana sehingga nantinya dapat diperoleh hasil maksimal terutama guru dan siswa sebagai masyarakat dalam pembelajaran dikelas. Ini sejalan dengan Nismawanti (2019) bahwa pembelajaran berbasis lingkungan dengan menggunakan problem based learning dapat menjadikan kemampuan dan disposisi berpikir reflektif matematis berkembang. Oleh karena itu pembelajaran dengan berbasis lingkungan dapat dijadikan alternatif untuk mengembangkan suatu pembelajaran.

3. Rata-rata effect size model pembelajaran berbasis penemuan dan model pembelajaran berbasis lingkungan

Berdasarkan analisis data nilai effect size model pembelajaran berbasis penemuan dan model pembelajaran berbasis lingkungan diatas, dapat diperoleh nilai rata-rata effect size dari kedua model pembelajaran yang dianalisis. Berikut adalah tabel hasil ringkasan perhitungan rata-rata nilai effect size dari kedua model pembelajaran tersebut.

Tabel 5. Rata-rata nilai effect size model pembelajaran berbasis penemuan (BP) dan model pembelajaran berbasis lingkungan (BL)

\begin{tabular}{ccc}
\hline Tahun & $\boldsymbol{E S}_{\boldsymbol{B P}}$ & $\boldsymbol{E} \boldsymbol{S}_{\boldsymbol{B} \boldsymbol{L}}$ \\
\hline 2016 & 0,941 & 1,177 \\
2017 & 0,777 & 1,866 \\
2018 & 0,712 & 1,070 \\
2019 & 0,618 & 0,866 \\
$\sum_{\bar{x}_{E S}} x_{i}$ & 3,048 & 4,979 \\
\hline
\end{tabular}

Berdasarkan Tabel 5, nilai ratarata effect size model pembelajaran berbasis lingkungan lebih baik dari pada model pembelajaran berbasis penemuan terhadap kemampuan pemecahan masalah matematika selama 4 tahun 
terakhir (2016-2019) di wilayah Jawa Tengah. Selisih nilai rata-rata effect size dari model pembelajaran berbasis penemuan dengan model pembelajaran berbasis lingkungan tidak terlalu jauh. Nilai rata-rata effect size kedua model pembelajaran tersebut disajikan pada Gambar 5.

\section{RATA-RATA EFFECT SIZE}

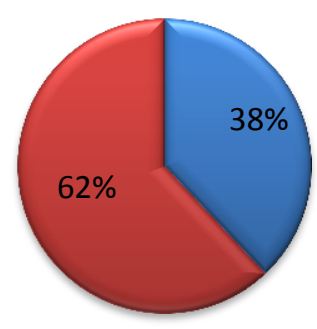

$\square$ Model

Pembelajaran

Berbasis

Penemuan

a Model

Pembelajaran

Berbasis

Lingkungan

Gambar 5. Diagram Nilai Rata-rata Effect Size

\section{Faktor penyebab terjadi perbedaan pengaruh model pembelajaran berbasis lingkungan dan model pembelajaran berbasis penemuan terhadap kemampuan pemecahan masalah matematika.}

Berdasarkan review dan analisis hasil penelitian tentang model pembelajaran berbasis penemuan dan model pembelajaran berbasis lingkungan terhadap kemampuan pemecahan masalah matematika selama 4 tahun terakhir (2016 - 2019) di wilayah Jawa Tengah, terdapat faktorfaktor yang mendorong kemampuan pemecahan masalah matematika yaitu : 1) adanya bantuan media sehingga siswa mampu memahami masalah dengan efektif dan mampu meningkatkan kemampuan pemecahan masalah yang dihadapi, 2) adanya media dapat membimbing siswa dalam menyelesaikan masalah dan membuat siswa lebih tertarik dalam proses belajar mengajar, 3) adanya keaktifan siswa dalam menerapkan konsep matematika dan model matematika dalam memecahkan permasalahan, 4) adanya pengaruh motivasi belajar siswa, sehingga siswa dapat menyelesaikan permasalahan dan timbul rasa ingin tahu dalam pembelajaran, 5) adanya kegiatan diskusi kelompok yang mengakibatkan siswa lebih aktif dan siswa mampu meningkatkan kemampuan pemecahan masalah dalam proses pembelajaran. Hal ini sesuai dengan faktor yang mempengaruhi kemampuan pemecahan masalah dimana faktor tersebut dikelompokkan menjadi dua, yaitu komponen kemampuan analitis yang terdiri dari mengidentifikasikan masalah dan menentukan tujuan serta komponen kemampuan sistematis yang terdiri dari menentukan strategi yang mungkin, melaksanakan strategi dan memeriksa kembali (Dwianjani, 2018). Selain itu, faktor penting yang mempengaruhi pemecahan masalah diantaranya adalah faktor kepercayaan diri siswa agar siswa dapat berpartisipasi aktif, kreatif dan mandiri selama proses pembelajaran (Ramdan, 2018). Hasil penelitian ini sejalan dengan penelitian yang dilakukan oleh Al Ayyubi, dkk. (2018); Bernard, dkk. (2018); Anugraheni (2018); Widayati, dkk. (2018); Nugroho \& Dwijayanti (2019).

Implikasi berdasarkan hasil penelitian ini yaitu pemilihan dan penggunaan model pembelajaran yang tepat dapat mengoptimalkan proses dan hasil belajar. Disamping itu, kemampuan pemecahan masalah dapat meningkatkan hasil belajar siswa melalui mengintegrasikan konsep atau media dengan model pembelajaran yang tepat. 
DOI: https://doi.org/10.24127/ajpm.v9i1.2659

\section{KESIMPULAN DAN SARAN}

Berdasarkan hasil penelitian ini, maka dapat disimpulkan bahwa pengaruh model pembelajaran berbasis penemuan terhadap kemampuan pemecahan masalah matematika cenderung menurun setiap tahunnya. Sedangkan pengaruh model pembelajaran berbasis lingkungan terhadap kemampuan pemecahan masalah matematika cenderung tidak stabil setiap tahunnya.

Rata-rata kemampuan pemecahan masalah matematika dengan menggunakan model pembelajaran berbasis lingkungan cenderung lebih baik hasilnya dibandingkan rata-rata kemampuan pemecahan masalah matematika menggunakan model pembelajaran berbasis penemuan. Selain itu, faktor-faktor yang mempengaruhi keberhasilan model pembelajaran berbasis penemuan dan model pembelajaran berbasis lingkungan terhadap kemampuan pemecahan masalah matematika cenderung disebabkan oleh bantuan media dalam pelaksanaan pembelajaarannya.

Saran bagi yang akan menggunakan model pembelajaran berbasis penemuan dan model pembelajaran berbasis lingkungan untuk lebih memperhatikan sintaksis atau langkah-langkah serta menganalisis kebutuhan siswa dan materi yang akan disampaikan, termasuk media yang akan digunakan.

\section{DAFTAR PUSTAKA}

Al Ayyubi, I. I., Nudin, E., \& Bernard, M. (2018). Pengaruh Pembelajaran Berbasis Masalah Terhadap Kemampuan Pemecahan Masalah Matematis Siswa SMA. JPMI (Jurnal
Pembelajaran Matematika

Inovatif), 1(3), 355-360.

Anggreni, Y. D., Festiyed, F., \& Asrizal, A. (2019). Meta-Analisis Pengaruh Model Pembelajaran Project Based Learning Terhadap Kemampuan Berpikir Kritis Peserta Didik SMA. Pillar of Physics Education, 12(4).

Anugraheni, I. (2018). Meta Analisis Model Pembelajaran Problem Based Learning dalam Meningkatkan Keterampilan Berpikir Kritis di Sekolah Dasar [A Meta-analysis of ProblemBased Learning Models in Increasing Critical Thinking Skills in Elementary Schools]. Polyglot: Jurnal Ilmiah, 14(1), 9-18.

Bernard, M., Nurmala, N., Mariam, S., \& Rustyani, N. (2018). Analisis Kemampuan Pemecahan Masalah Matematis Siswa SMP Kelas IX Pada Materi Bangun Datar. SJME (Supremum Journal of Mathematics Education), 2(2), 7783.

Dwianjani, N. K. V., \& Candiasa, I. M. (2018). Identifikasi Faktor-Faktor yang Mempengaruhi Kemampuan Pemecahan Matematika. NUMERICAL:

Jurnal Matematika dan Pendidikan Matematika, 153-166.

Glass, G. V., McGaw, B., and Smith, M. L. 1981. Meta-analysis in Social Research. Beverly Hills (California) : Sage Publications. Inc.

Gustika, R., Sakti, I., \& Putri, D. H. (2018). Implementasi Model Pembelajaran Penemuan (Discovery Learning Model) untuk Meningkatkan Keterampilan Berpikir Kritis dan Hasil Belajar Fisika Di SMAN 3 
DOI: https://doi.org/10.24127/ajpm.v9i1.2659

Bengkulu Tengah. Jurnal

Kumparan Fisika, 1(1), 1-6.

Islamiah, N., Purwaningsih, W. E., Akbar, P., \& Bernard, M. (2018). Analisis Hubungan Kemampuan Pemecahan Masalah Matematis dan Self Confidence Siswa SMP. Journal on Education, 1(1), 47-57.

Nismawati, N., Nindiasari, H., \& Mutaqin, A. (2019). Meningkatkan Kemampuan Berpikir Reflektif Matematis Melalui Model Pembelajaran Problem Based Learning Berbasis Lingkungan. JPPM (Jurnal Penelitian dan Pembelajaran Matematika), 12(1).

Nugroho, A.A., \& Dwijayanti, I. (2019). Analisis Kemampuan Pemecahan Masalah Mahasiswa Calon Guru Matematika Pada Mata Kuliah Program Linier. AKSIOMA: Jurnal Matematika dan Pendidikan Matematika 10 (2), 277-284.

Permendiknas (2006). Peraturan Menteri Pendidikan Nasional Nomor 22 Tahun 2006 Tentang Standar Isi untuk Satuan Pendidikan Dasar dan Menengah. Jakarta: Kemendiknas-Depdiknas.

Polya, G. (1973). How to solve it. New Jersey: Princeton University Press.

Purwati, H., Wuri, D.E., Nugroho, A.A., \& Dwijayanti, I. (2017). Meta Analisis Pengaruh Model Pembelajaran Kolaboratif Dan Kompetitif Di Jawa Tengah Dalam Tiga Tahun Terakhir. Prosiding Seminar Nasional Matematika dan Pendidikan Matematika (SENATIK).

Ramdan, Z. M., Veralita, L., Rohaeti, E. E., \& Purwasih, R. (2018). Analisis Self Confidence
Terhadap Kemampuan

Pemecahan Masalah Matematis Siswa Smk Pada Materi Barisan Dan Deret. AKSIOMA: Jurnal Program Studi Pendidikan Matematika, 7(2), 171-179.

Rangkuti, M. A., \& Sani, R. A. (2018). Analisis Kemampuan Berfikir Kritis Menyelesaikan Masalah Fisika Pada Pembelajaran Dengan Model Pembelajaran Inkuiri. INPAFI (Inovasi Pembelajaran Fisika), 6(3).

Sembiring, E. (2019). Kemampuan Pemecahan Masalah Matematika Melalui Beberapa Model Pembelajaran. INA-Rxiv preprints.

https://doi.org/10.31227/osf.io/vfu i4

Setiawan, H., Setiany, E. P., Andiarani, M., \& Hidayat, W. (2018). Meningkatkan Kemampuan Berpikir Kreatif Matematik Siswa Sekolah Menengah Kejuruan Melalui Model Pembelajaran Inquiry Guided. Jurnal Pendidikan Tambusai, 2(6), 17391745.

Suryany, N., Anwar, M., \& Danial, M. (2018). Pengaruh Model Pembelajaran Penemuan (Discovery Learning) Terhadap kesadaran Metakognisi dan Penguasaan Konsep Larutan Penyangga Pada Peserta Didikkelas XI IPA SMAS Makassar Raya. Chemistry Education Review (CER), 100116.

Utami, R. E., Nugroho, A. A., Dwijyanti, I., \& Sukarno, A. (2018). Pengembangan E-Modul Berbasis Etnomatematika Untuk Meningkatkan Kemampuan Pemecahan Masalah. JNPM 
DOI: https://doi.org/10.24127/ajpm.v9i1.2659

\section{(Jurnal Nasional Pendidikan}

Matematika), 2(2), 268-283.

Wahyuningsih, S. S., Darmayanti, T., \&

Bintarti, A. (2019). Meta Analisis

Tutorial Online Universitas

Terbuka. Jurnal Pendidikan

Terbuka Dan Jarak Jauh, 20(1), 32-38.

Widayati, W., Suyono, S., \& Rahayu,

W. (2018). Pengaruh Model

Pembelajaran Berbasis Penemuan

Terhadap Kemampuan Berpikir

Kritis Matematis Dan Self

Concept Dengan Mengontrol

Kemampuan Awal Peserta Didik

Kelas VII SMP. JPPM (Jurnal

Penelitian dan Pembelajaran

Matematika), 11(1).

Wuryastuti, S., \& Ni'mah, I. (2013).

Model Pembelajaran Berbasis

Lingkungan Untuk Meningkatkan

Kecakapan Hidup Mahasiswa

Melalui Pembuatan Kompor

Biogas. EDUHUMANIORA:

Jurnal Pendidikan Dasar, 5(2). 